\title{
Significance of Disease in Modern Society and the Psychological State of Human Facing Disease
}

\author{
Ziyuan $\mathrm{Xu}^{1, *}$ \\ ${ }^{1}$ Beijing No.4 High School International Campus, Xicheng District, Beijing 100054, China
${ }^{*}$ Corresponding author. Email: xuziyuan01234@hotmail.com
}

\begin{abstract}
French writer Albert Camus, in his novel La Peste, tells the story of an outbreak of plague in the city of Oran. During the pandemic, a group of people are led by the main character, Dr. Rieux, struggle to fight the disease, while other characters take different actions and attitudes from Dr. Rieux. By reflecting the concept of La Peste into real life, Camus shows the idea of existentialism, that is, no matter what kind of suffering people face, they should make objective judgment and strive to fight. Given the outbreak of COVID-19 in 2019, fighting the disease and maintaining a rational mind, even after the initial panic or the later numbness, can help people turn the tide and demonstrate the fearless spirit of liberal humanitarianism.
\end{abstract}

Keywords: Disease, Albert Camus La Peste, existentialism

\section{INTRODUCTION}

Camus was born in 1913 to laborers French Algeria in North Africa. His father was conscripted to fight in the World War I shortly after he was born, and young Camus was brought up by his mother in her hometown. After middle school, Camus began to work while studying. Although the life was hard, the warm climate of Algeria near the Mediterranean Sea deeply inspired Camus's thought and spirit, and later became the symbol of his "southern ideology" system, as opposed to the northern thought suggested by the German thinkers.

After graduating from university, Camus worked as a journalist, reporting on the plight of Muslims and many of Algeria's lower and middle working classes, also participated in political movements and organized theater groups to express their views. After the outbreak of the World War II, Camus went to Paris to work as the newspaper he had served in Algeria was shut down. Camus began writing plays, novels and essays in Algeria. After the publication of L'Étranger in 1942, Camus began to win acclaim in France and abroad. In 1957, he won the Nobel Prize for Literature, with the Swedish Academy praising his work as "clearly insightful, sincere and illuminating the conscience of the contemporary people." Camus passed away in a car accident in France in 1960 .
Camus' works are diverse and are divided into several stages. The first stage of his "absurd series" includes the novel L'Étranger, the drama Caligula and Le Malentendu, and the treatise Le Mythe de Sisyphe. The second stage of the "rebellion series" includes the novel La Peste, the treatise L'Homme Révolté and the drama Les Justes. His other works include La Chute, La Mort Heureuse, L'Exil et le Royaume, and his final work Le Premier Homme, as well as the drama Létat de Siège and Dämonen, adapted from Dostoevsky's novel.

La Peste belongs to Camus' "rebellion series", and its main purpose is to describe and explain the connotation and process of rebellion. In the city of Oran, which was closed down due to the plague, there were fearful citizens who were constantly on the alert, speculators who tried their best to escape the city, guards or merchants who took the opportunity to make money from the disaster, authorities, some doctors and experts who were reluctant to face up to the problem. These were all human nature. However, Camus focused more on Dr. Rieux who devoted himself to saving lives, M. Othon, whose son was infected yet insisted everything goes by the law, Dr. Castel who studied the serum, Joseph Grand as a humble but indispensable epidemic statistics of the small staff, Raymond Rambert who was forced to stay in Oran. Everyone was doing their best to rise up against the epidemic and united together to fight, which was also human nature. Through La Peste, Camus promoted from "absurdity" to "unity", from "individual struggle" to 
"collective destiny", from "pursuit of the ego" to "fulfillment of the the greater self", and once again showed his beloved, optimistic and resilient "southern ideology" (La Pensee de Midi).

\section{RELATIONSHIP BETWEEN DISEASE AND LITERATURE}

There are various definitions and descriptions of diseases. According to the Oxford English Dictionary (OED), disease refers to "a medical problem affecting humans, animals or plants, often caused by infection." [1] In Illustrated Medical Dictionary, it is considered as an abnormal process of life activities due to the disorder of auto-regulation caused by damaging effects of certain reasons. It is a pathological condition that affects part or all organs of an organism, and is generally interpreted as a "medical condition" accompanied by specific symptoms and medical signs [2]. The body has a series of anti-damage reactions to the injuries caused by pathogenies; The stability adjustment disorder, the damage, and the antinociception are illustrated as all kinds of abnormal alternations of complex function, metabolism and morphology. These changes would lead to the obstacles of coordination between the body and organ systems, as well as the body and the external environment disorders, resulting in a variety of symptoms, signs and abnormal behaviors, especially the lost of ability to adapt to the environment and physical strength. [3] Therefore, disease is one of the causes of biological regulation disorder or abnormal vital signs, however, the manifestation of it is more complex than the definition describes in real-life situations. It can negatively affect people with discomfort (though sometimes without signs of discomfort) and difficulties in their behaviors on account of cellular damage or a change in intellection. For instance, trauma resulting from an external attack and psychological alternation led by mental injury can both be counted as diseases. At the same time, disease can also greatly affect the development of human society and the way people behave. When Coronavirus first being recognized, there was a rush to stock up in some regions, and crime rates skyrocketed while unemployment rate increased, just as there were more than 200 shootings on Independence Day in the United States in 2021, resulting in more than 100 deaths. There are many other similar examples. Obviously, disease can give rise to panic and agitation that may cause social chaos. Yet, its depiction in literature tend to be more uncertain. Writers often include disease in their works in order to create an atmosphere of mystery or claustrophobia, or to symbolize concepts that are difficult to articulate in a few words. Tuberculosis, for example, which frequently appeared in 19th century literature, is described by many critics as a symbol of the depletion of life, while autism and depression represented a state of character isolation. But these are not real diseases. Different from these examples, in the novel La Peste, Albert Camus describes the plague objectively by using straightforward language to illustrate the visible consequences and damage caused by the disease. The book is conceived in 1940, when the German army invaded Paris and began killing the French. In 1942, Camus suffered a relapse and was cut off from the outside world. In such pressure caused by the enormous background and health condition, as Susan Sontag depicted in the Illness as Metaphor: "Epidemic have often been used as a rhetorical technique to describe social chaos. The noun, fatal, derived from bubonic plague, according to Oxford English Dictionary, has the metaphorical meaning of harmful to the religious, moral, or public peace." [4] Camus uses La Peste to show people's panic and confusion in the face of the holocaust, and also believes that it is important and great to persist in resistance and truth in despair. Although he uses the disease to allude to the current state of life, he begins the story with a very specific description of the symptoms and clinical procedures of plague patients. There is a sharp contrast between the mental state of people described in the first half of the story and in the later period, indicating that diseases have a great impact on society.

Disease can easily cause negative emotions in people. To some extent, it represents the bewilderment and puzzlement in the face of the unknown, as well as the smallness and helplessness of human when facing the death. In the $21 \mathrm{st}$ century, the rapid development of medical science has solved a large proportion of common diseases in people's lives, even if some have not yet found a way to guarantee $100 \%$ cure, their causes are no longer a mystery. However, such progress does not mean that people can remain calm in the midst of illness, without fear of the unknown and death. Some of the most striking differences between a diseased world and a normal one is that the former can sensitize and desensitize people's thoughts and actions, leading to chaos and conflicts which are less common in the latter. In La Peste, Albert Camus unfolds the process of the plague's intrusion into human life step by step, from peace at the beginning to panic and chaos, then to numbness and carnival at the end. In a world that had not yet been invaded by plague, people were less alert, ignoring or not paying attention to even a hint of something unusual.

\section{THE SPREAD OF DISEASE AND PEOPLE'S ATTITUDES TOWARDS IT IN LA PESTE}

La Peste begins with the discussion of death, a collective death faced by all. Yet when facing this uncontrollable fate, people all had their distinct reactions: some did not understand the situation, some wanted to run away... One character even turned out to have made a fortune out of the disaster. There were others, like Dr 
Rieux, an ordinary city clerk, and a person who had come to this town with some unknown reasons, who knew their job was to save lives. "What on earth can we do here?" he asked. "What's the point?" They organized volunteer medical teams to help others, such as arranging vaccinations, taking patients to hospital or returning home. Although they knew that those who caught the plague would only live by very little chance, this man of unknown origin said, "Now that we are in this hopeless situation, facing such a collective fate, we should fight rather than wait and die. If we still want to have a chance to change our fate, we can only do so." The people who organized the medical teams, however, ended up dying. One of them exhorted Dr Rieux before his death: "If you want to show Death that you have control over your life, then keep fighting even though you know the lose is certain, for only in this way can you show that your life has meaning, and if you can give a meaning to your life, you can show your freedom." This speech summarizes Camus' views on the significance of life, freedom, and dignity of humanity.

How should people settle into this modern world and reveal their meaning of life? It is only through their own participation and actions, that meaning is created, not in the way of God's production out of nothing, but in the contingent, the absurd, and the multitude of things that cannot be explained. This is the value of human, the value called "love". This expression often appears in the novel, just like the Buddhist "compassion" which suggests people to lend a helping hand to others suffering. Even if they fail, or even if the chance of success is minimal, people shall not give up any possible opportunity to try to change the collective destiny.

In the book, Dr. Rieux spotted a dead mouse and at first ignored it, "merely kicking the small animal away."

[5] Although he immediately realized that the rat had "died in a bad place" and informed the doorman about it, he did not take further investigation but acquiesced in M. Michel's idea of "prank." [6] So, it had been for some time. Dr. Rieux was surprised and puzzled, yet the cold and disapproving reactions of those around him limited his actions and suspicions. [7] This is because people have lived in a disease-free world for a long time, resulting in their lack of anticipation of the worst development and low vigilance, even if they sometimes choose to ignore the clues out of fear of trouble and indifference. However, once the existence of plague was confirmed, the atmosphere in the city became sensitive and a wave of panic and chaos erupted. It was the smallest details that scare them. The increasing number of rats and the emergence of more cases, beginning with the death of the concierge, "increased the panic" and

brought "anxiety to its peak." [8] As the disease spread violently, people began to enter the morbid world where the fear of the unknown and death provoked moral standards, and confusion intensified contradictions among people. The whole town lost its calmness with only a few people remained sane. The police had no time for criminals, letting Cottard to roam at large and hiding in the shadow of the plague; Citizens became "humanitarians" as they paid no attention to the instruction and were the first to be attacked by the virus. Living people "raised torches and fought with each other, preferring their heads to break and bleed." [9] [10] The law and morality rendered worthless by the threat of death in a sickly world full of chaos and cannibalism. They justified their behaviors with "humanitarian

issues", but failed to realize that preserving the majority through order was also a moral issue. [11] In this way, contradictions gradually emerged in the society, while some people even longed for a real earthquake. [12] They lost their calm empathy and became different from what they were before, wishing for simpler and more extreme ways to end their lives disrupted by panic rather than put a solution to the real pain of illness. Those patients were the ones who want to live, while others only wanted to be freed from fear in this macabre environment. With the passage of time, the city acquiesced to the existence of plague, and "the initial impulse and resentment have disappeared", which could be regarded as "a temporary recognition." [13] People had adapted to the environment. Although it was still painful, "but [they] can no longer

feel it." They forgot the memories and fears of the past, not only for the loved ones who were far away, but also for the dead. The hopes and expectations for the future were fading. The plague took away people's feelings and left them "destitute." Despite the fact that they were sometimes "stirred up by the sight" and stung by the wounds that had not yet been healed, they understood the so-called reality and emptiness and quickly returned to the "prison of plague." [14] The whole atmosphere went numb. Whether it was the process of moving the sick and the dead, or the urgency of being reunited with family and loved ones, they were gradually replaced by "a blind stubbornness" and "a strange indifference." [15] [16] However, in this callousness, revelry, once rare in the normal world, had spread among people. They "made merry", lived "a Bohemian life of pleasure", "spent money freely" at soaring prices, and couples "roamed the city with abandon." [17] It was an orgy far more wild 
than any celebration in the normal world. It was only when the attitude towards death shifts from fear to numbness and to resignation that such a breach of moral boundaries or values occurs.

Yet, in spite of this insensitive situation, there were still those who struggle with their will. For example, at a time when medical resources and human resources were scarce, Dr. Castel repeated experiments, developed a serum against the plague, which became people's last hope; Rambert, a journalist, tried to leave Paris because he was worried about his girlfriend, but after the chaos, he decided to stay and fight against the disease and death together with Dr. Rieux. [18] [19] These characters stood out from the atmosphere of numbness and madness, reflecting a rational spirit and way of thinking in the face of despair.

\section{THE EXISTENTIAL SIGNIFICANCE AND VALUE OF INDIVIDUAL CHOICE IN LA PESTE}

People's attitudes changed over and over when facing the threat of disease, but their hope for life was erased from the very beginning. Against such a background of despair and absurdity, Camus made use of the character and their views of dealing with affairs to emphasize the spirit of resistance, which was also his solution given to the audiences as an existentialist. He believes that even the death is fearful and the atmosphere around him became numb, he should take objective actions instead of accepting them all, so as to realize the meaning of his existence. Just like Dr. Rieux, after clearly recognizing the seriousness of the matter, he did not abandon the world he was tired of, yet tried his best to rescue the dying and the wounded, and did his duty as a doctor. He did not believe in God, and only relied on his down-toearth efforts to save the suffering patients. The Father Paneloux, in contrast to Dr. Rieux, was a figure Camus tries to disavow. Father Paneloux believed in the power of God and waited for miracles to come. Even when he saw the tragic death of the little girl, he was still unwilling to question this belief. At the last moment, he died on a hospital bed holding a cross. This kind of attitude of waiting for others to redeem oneself without trying to resist spontaneously is opposed to self-shaping and the pursuit of centering on people, which the existentialism advocates.

After the second world war, the philosopher, Saudi Arabia, put forward the term of "existentialism" for the first time, and in his personal speech, existentialism was described as "attempts to depict all consequences from the position of faithful atheism." This thoughts, which was based on the world where "God is dead" and the value of human existence had shaken, had a major impact on Camus, the author of La Peste. Jean-paul Saud has a maxim: "Existence precedes essence." [21] What he meant was that there is no preordained morality or soul other than the man himself. Morality and soul are created by man in his existence. People are not obliged to follow a moral standard or religious belief that they have the freedom to choose. When evaluating a person, it is his behavior that should be evaluated rather than his identity, because his essence is defined through behavior, that is, "a person is the sum of his behavior." [22] This regression to humanism can be interpreted in literature when people assign the criteria for evaluating personal value to themselves. In fact, through the work, Camus wants to express that the "plague" in everyone's mind will inevitably be exploded when the disaster comes. People can become apathetic, which is lamentable but possibly forgivable, after all, most people are helpless in the face of disaster, and the only goal left is to survive. It is for this reason that those who dare to resist in the midst of disaster are set off as great. This greatness is not due to their contributions or expertise, but because they know what they should do and are not controlled by the "plague" in their hearts. In the novel, Dr. Rieux, Tarrou, Rambert, and some other characters are such people with great spirit of resistance. "One cannot heal the illness and know everything at the same time. Then we shall cure people as soon as possible. That is the priority." An epidemic can reveal both the ugliness and brilliance of human nature. Under the plague, no one is free and must choose a common destiny: to revolt. These people fight to the extent that they can instead of giving up. "Face the absurd fate". Without relying on God, they achieve their own duty, and show the meaning of existence in the resistance.

\section{CONCLUSION}

In the background of plague, Camus narrates the horror of extreme disasters, explaining from a different perspective that resistance is the only option. As an existentialist writer, Camus emphasizes the concept of "Existence precedes essence" in his work. There are no necessary norms and rules except human existence, and only one's own resistance can realize the freedom of existence. Otherwise, various "plagues" will send people into exile. Pestilence, freedom and death are always interwoven, depending on the individual's choice. And a plague can change one's perspective on whether the meaning of life depends on social values or his own understanding. The absurdity of life is that pestilence is everywhere, and individuals are driven to the corner of exile and even pay the price of their lives. How can they escape from the shackles of irrationality?

What is plague? It is life. It is everything in life that limits personal freedom.

Then, how should people face the threat of such a disaster in real life? At the end of 2019, when the Coronavirus was first revealed and unfolded its untreatable properties, the population became flustered, blaming one another, and even suggesting that nature had 
given humanity a cleansing. Such extreme thoughts and actions were in fact no different from those of Father Paneloux, who passively await external salvation rather than change the situation spontaneously.

In 2020, various anti-virus policies were introduced. In 2021, a Coronavirus vaccine was developed and vaccination campaigns were carried out everywhere around the world. It turned out that being positive, objective and rational could reverse desperate dilemmas, just like Dr. Rieux did. Although, in La Peste, Dr. Rieux's behavior did not contribute much to the disappearance of the epidemic, his way of dealing with the reality that he could hardly change provides the audiences with a choice of resistance, and allows them to realize the meaning of their own existence while saving others.

\section{REFERENCES}

[1] Pearsall, J. (2018). Oxford Reference. Retrieved from https://www.oxfordreference.com/view/10.1093/ac ref/9780199571123.001.0001/acref9780199571123

[2] Illustrated Medical Dictionary Full Book. (2004). Retrieved from https://allnextbooks.com/get/access.php?id=mNA Cis YwbZoC\&item=Dorland\%20S\%20Illustrated\% 20Medical\%20Dictionary\%20E\%20Book

[3] Retrieved from https://zh.wikipedia.org/wiki/Disease\#cite_note-1

[4] Sontag, S. (2018). Illness as Metaphor and AIDS and Its Metaphors. Shanghai Translation Publishing House.

[5] Sontag, S. (2018). Illness as Metaphor and AIDS and Its Metaphors. Shanghai Translation Publishing House.

[6] Sontag, S. (2018). Illness as Metaphor and AIDS and Its Metaphors. Shanghai Translation Publishing House.

[7] Sontag, S. (2018). Illness as Metaphor and AIDS and Its Metaphors. Shanghai Translation Publishing House.

[8] Sontag, S. (2018). Illness as Metaphor and AIDS and Its Metaphors. Shanghai Translation Publishing House.

[9] Sontag, S. (2018). Illness as Metaphor and AIDS and Its Metaphors. Shanghai Translation Publishing House.[10] Camus, A. (2013). L’Étranger · La Peste (3rd ed.). The Yilin Press.

[11] Camus, A. (2013). L’Étranger • La Peste (3rd ed.). The Yilin Press.
[12] Camus, A. (2013). L'Étranger • La Peste (3rd ed.). The Yilin Press.

[13] Camus, A. (2013). L’Étranger • La Peste (3rd ed.). The Yilin Press.

[14] Camus, A. (2013). L'Étranger • La Peste (3rd ed.). The Yilin Press.

[15] Camus, A. (2013). L'Étranger • La Peste (3rd ed.). The Yilin Press.

[16] Camus, A. (2013). L'Étranger • La Peste (3rd ed.). The Yilin Press.

[17] Camus, A. (2013). L'Étranger • La Peste (3rd ed.). The Yilin Press.

[18] Camus, A. (2013). L'Étranger • La Peste (3rd ed.). The Yilin Press.

[19] Camus, A. (2013). L'Étranger • La Peste (3rd ed.). The Yilin Press.

[20] Jean-Paul Sartre. Xunliang Zou,Yongkuan Yang. Shanghai Translation Publishing House. 2012-6-1

[21] Jean-Paul Sartre. Xunliang Zou,Yongkuan Yang. Shanghai Translation Publishing House. 2012-6-1

[22] Jean-Paul Sartre. Xunliang Zou,Yongkuan Yang. Shanghai Translation Publishing House. 2012-6-1 